\title{
A new Genus and new Species of Carpenter-Moths (Lepidoptera: Cossidae: Hypoptinae) from southern Argentina
}

\author{
Новый род и новый виА Аревоточщев (Lepidoptera: Cossidae: \\ Hypoptinae) из южкной Аргентины
}

\author{
F.C. Penco ${ }^{1}$, R.V. Yakovlev ${ }^{2,3}$, A.E. Naydenov ${ }^{2}$ \\ Ф.Ц. Пенко ${ }^{3}$, Р.В. Яковлев ${ }^{2,3}$, А.Е. Найдёнов ${ }^{2}$
}

\footnotetext{
${ }^{1}$ Fundación de Historia Natural "Félix de Azara", Departamento de Ciencias Naturales y Antropología, Universidad Maimónides, Hidalgo 775 piso 7 (1405BDB) Ciudad Autónoma de Buenos Aires, Argentina. E-mail: fernando_penco@hotmail.com

2 Altai State University, pr. Lenina 61, Barnaul, 656049, Russia. E-mail: colias24@mail.ru; yakovlev_asu@mail.ru

3 Tomsk State University, Laboratory of Biodiversity and Ecology, Lenina pr. 36, 634050 Tomsk, Russia.

2 Алтайский государственный университет, пр. Ленина 61, Барнаул, 656049, Россия.

3 Томский государственный университет, Лаборатория биоразнообразия и экологии, пр. Ленина 36, Томск, 634050, Россия.
}

KEY WORDS: Cossidae, new genus, new species, taxonomy, carpenter moths, South America.

КЛЮЧЕВЫЕ СЛОВА: Cossidae, новый род, новый вид, таксономия, древоточцы, Южная Америка.

ABSTRACT. A new genus is erected and characterized "Schajovskoia Penco, Yakovlev et Naydenov, gen.n. (Lepidoptera: Cossidae, Hypoptinae) with one new species described and illustrated within it: Schajovskoia albomaculata Penco, Yakovlev et Naydenov, sp.n. from southern Argentina. The description is illustrated with the images of adults, the wings venation and male genital structures. The geographical distribution is provided.

РЕЗЮМЕ. Выделен новый монотипный род “ Schajovskoia Penco, Yakovlev et Naydenov, gen.n. (Lepidoptera: Cossidae, Hypoptinae) с типовым видом Schajovskoia albomaculata Penco, Yakovlev et Naydenov, sp.n. из Южной Аргентины. Описание проиллюстрировано изображениями имаго, гениталий самцов, жилкованием крыльев. Также дана карта распространения нового вида.

\section{Introduction}

The fauna of Cossidae from Neotropical region has been scarcely studied during last century and it is still poorly known. In recent years, there has been some progress in the research on the family, with descriptions of new genera and species [Donahue, 1980; Gentili, 1989; Schoorl, 1990; Davis et al., 2008; Penco, Yakovlev, 2017; Penco et al., 2019a, b; Naydenov et al., 2019], and redescriptions and better characterization of known genera [Yakovlev, 2014; Yakovlev et al., 2016;
2019; Penco et al., 2016].

The species of Neotropical Cossidae has been partially listed by Dyar and Schaus [1937], Gentili and Gentili [1988], Gentili [1989], Schoorl [1990], Donahue [1995], and Penco and Yakovlev [2015] the last listed the species from Argentina only.

During the examination of material deposited in collections of Argentina and Germany, we found specimens belonging to a species new to science, that have features in the genital structures that are unique between the Hypoptinae, in the size and shape of the phallus, which justified the creation of a new genus, its description is provided below.

\section{Materials and methods}

The male genitalia slides were examined with a Zeiss Stemi 2000 C microscope and Digital Microscope U500X, 1.3 MPx. The genitals were conserved in small vials pinned attached with the specimens. The images were taken with a Olympus XC-50 camera and Sony DSLR-A100K and edited with Adobe Photoshop CS.

The collections where the specimens were found are the Museo Argentino de Ciencias Naturales "Bernardino Rivadavia" (MACN), Museo de la Plata (MLP), Instituto de Microbiología y Zoologia Agrícola, INTA Hurlingham (IMZA), Museo Patagónico de Ciencias Naturales "Juan Carlos Salgado", Rio Negro (MPCN) and Museum of Thomas Witt, Munich (Germany) (MWM).

How to cite this article: Penco F.C., Yakovlev R.V., Naydenov A.E. 2020. A new Genus and new Species of Carpenter-Moths (Lepidoptera: Cossidae: Hypoptinae) from southern Argentina // Russian Entomol. J. Vol.29. No.2. P.210-213. doi: 10.15298/rusentj.29.2.16 


\section{Schajovskoia Penco, Yakovlev et Naydenov, gen.n.} Figs 1-6.

Type species (by monotypy) Schajovskoia albomaculata Penco, Yakovlev et Naydenov, sp.n.

DESCRIPTION. Size medium to small, antenna bipectinate, antenna processes 2.5 times longer than antenna rod diameter. Fore wing elongated, hind wing short and rounded. Fore wing dark, pattern poorly expressed. Hind wing grey, without pattern.

Venation (Fig. 5). On fore wing, distal end of Sc projected to the middle of costa length; R-cell tiny, twice smaller than M-cell; $\mathrm{R}_{1}$ departs from upper edge of $\mathrm{R}$-cell; $\mathrm{R}_{2}$ and $\mathrm{R}_{3}$ depart from top of $\mathrm{R}$-cell as one line, diverging in postdiscal area; $\mathrm{M}_{1}$ and $\mathrm{M}_{2}$ depart from top of $\mathrm{M}$-cell; $\mathrm{CuA}_{1}$ departs from top of $\mathrm{Cu} ; \mathrm{CuA}_{2}$ from border of middle and distal thirds of $\mathrm{Cu}$; $\mathrm{CuP}$ and $\mathrm{A}_{1+2}$ form anastomosis in postdiscal area. On hind wing, distal end of Sc reaches the border of middle and distal thirds of fore wing; R-cell reduced; M-cell tiny; space between bases of Rs" $M_{1}$ and $M_{2}-M_{3}$ significantly smaller than $\mathrm{M}_{1}-\mathrm{M}_{2} ; \mathrm{CuA}_{1}$ departs from top of $\mathrm{Cu} ; \mathrm{CuA}_{2}$ from the border of middle and distal thirds of $\mathrm{Cu}$; A-veins even, with equal spaces between them.

Male genitalia (Figs 3-4). Uncus long, thin, apically sharp; gnathos arms relatively short, not fused, gradually narrowing to apex; valve semi-oval with semicircular notch caudally, with increased sclerotization at edges and poorly expressed harpe abdominally; juxta robust, cup-like; saccus robust, pyramidal; phallus thin, long (twice longer than valve), strongly S-curved throughout the length, basally widened, slightly narrowing apically, vesica aperture in dorso-apical position, takes over $2 / 3$ of phallus in length, vesica without cornuti.

Female slightly larger than male, colour lighter, abdomen longer, antenna processes slightly shorter than those of male. Genitals not examined.

DIAGNOSIS. The new genus has significant distinctive features in the shape of the phallus, which differs from all other Neotropical genera of the subfamily Hypoptinae. The general external aspect reminds the species of the genus
Philiodoron Clench, 1957 (type species " Philiodoron cinereum Clench, 1958) but the apomorphic features in the genital structures and the size and shape of the phallus prove the difference between these two genera. The most significant characters are:

— in Schajovskoia gen.n., the phallus is thin, long, strongly S-curved along the entire length, while in Philiodoron it is short, robust, almost straight;

- in Schajovskoia gen.n., the saccus is robust, pyramidal, while in Philiodoron, it is elongated, with parallel edges, ETYMOLOGY. The new genus is named after the Forester engineer, resident of Lacar Lake, "Don" Sergio Schajovskoi (1902-1974). Born in Moscow, was a descendent of a Russian nobility in times of the Romanov Dynasty. He established in the Argentinian Patagonia at late forties [De Mena, 2014]. Joint founder of the Instituto Patagonico of Ciencias Naturales (IPCN). Enthusiastic naturalist and entomologist, donated all the material collected during his life to the Museo Argentino (MACN), Museo of La Plata (MLP) and Natural History Museum in Munich [Gentili, 2008]. Most part of the material and records of insects living in Patagonia Argentina in the fifties belong to him. In acknowledgement for his contribution to the Argentine entomology, it is grate to us to honour him with the name of this genus. The name of the genus is feminine.

COMPOSITION. The new genus includes only one species, here described below.

DISTRIBUTION. This genus is known only from Argentina: Mendoza, Neuquén, Rio Negro, San Juan and Buenos Aires.

\section{Schajovskoia albomaculata \\ Penco, Yakovlev et Naydenov, sp.n.} Figs $1-6$.

MATERIAL EXAMINED. Holotype: $\sigma^{7}$ ARGENTINIEN, Prov. Mendoza, S.W. Mendoza 17 km, 20 Nov 1998, Leg. A. Ugarte P., (Genitalpräparat Heterocera № 28.460), (MWM). (Figs 1, 3).

Paratypes: (printed in yellow label with black ink): $20^{7} 0^{7}$ ARGENTINA: Mendoza: 17 km SW, 20 Nov 1998, Leg. A. Ugarte, $1 \mathrm{~m}$ (Genitalpräparat Heterocera № 26.713) (MWM); $5 \sigma^{\top} \sigma^{\top}, 19$

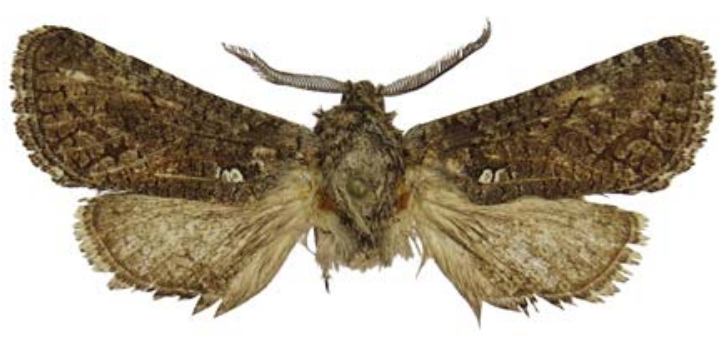

1

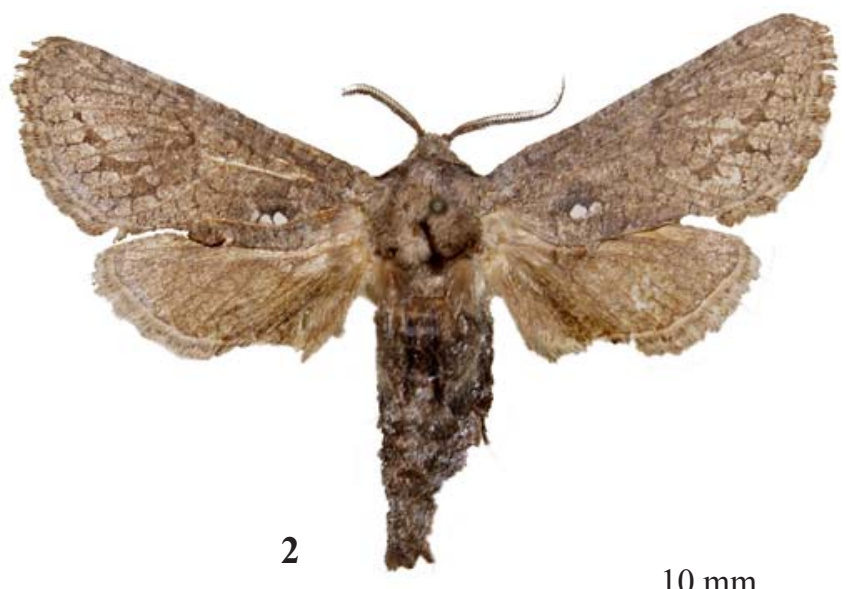

$10 \mathrm{~mm}$

Figs 1-2. Schajovskoia albomaculata, sp.n., adults: 1 - holotype, ơ, ARGENTINIEN, Prov. Mendoza, S.W. Mendoza 17 km, 20 Nov 1998, Leg. A. Ugarte P., (MWM); 2 - paratype, +, Neuquén: Laguna Blanca, 11 Ene 1970, Schajovskoi Leg., 5 m, (MACN).

Рис. 1-2. Schajovskoia albomaculata, sp.n., имаго: 1 - голотип, о', ARGENTINIEN, Prov. Mendoza, S.W. Mendoza 17 km, 20 Nov 1998, Leg. A. Ugarte P., (MWM); 2 — паратип, , Neuquén: Laguna Blanca, 11 Ene 1970, Schajovskoi Leg., 5 m, (MACN). 

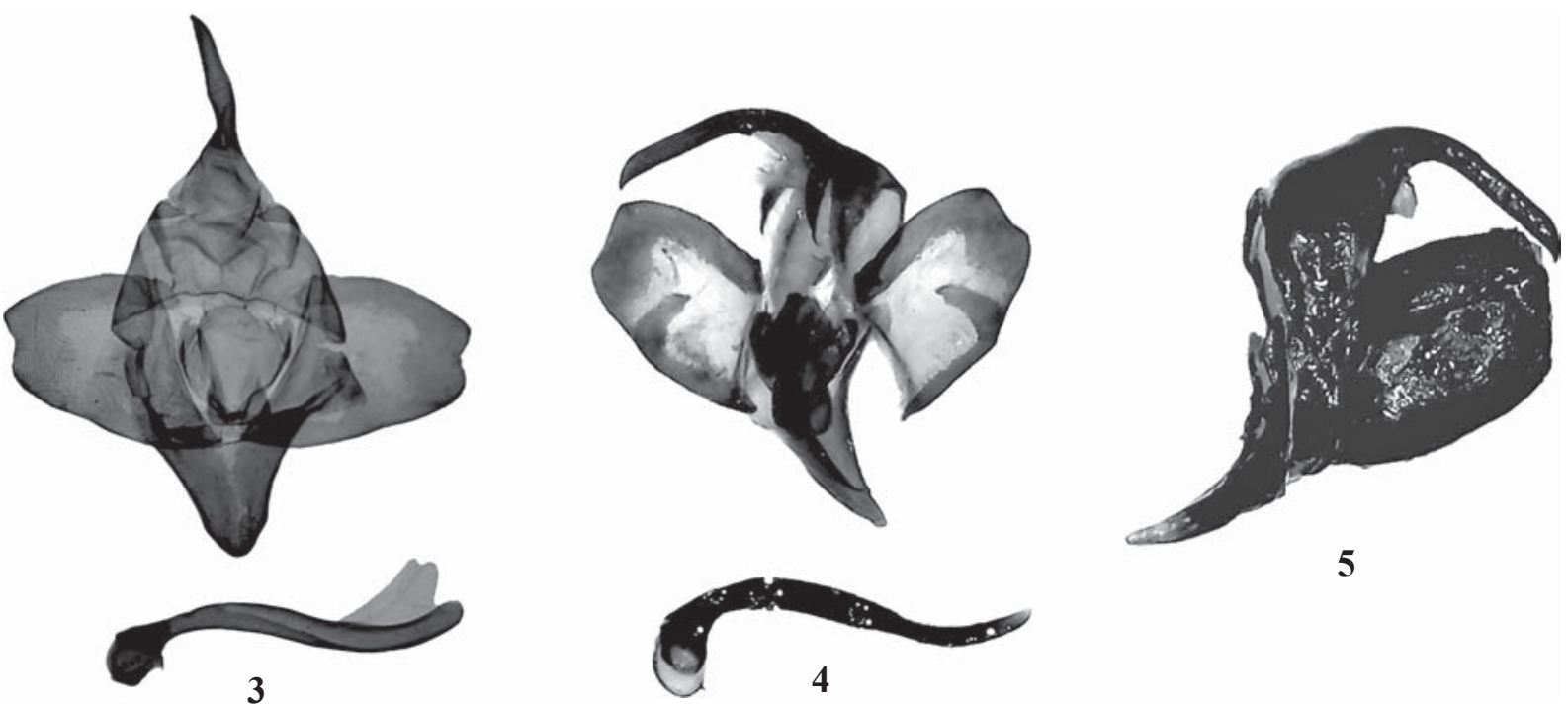

Figs 3-4. Schajovskoia albomaculata, sp.n., male genitalia: 3 - holotype, ơ', ARGENTINIEN, Prov. Mendoza, S.W. Mendoza 17 km, 20 Nov 1998, Leg. A. Ugarte P., (Genitalpräparat Heterocera № 28.460) (MWM); 4 — paratype, Ơ', Rio Negro, Choele Choel, 17 Feb 1953 , P. Köhler Leg., (Prep.Gen. MLP N³) (frontal and lateral $(*)$ projections) (MLP).

Pис. 3-4. Schajovskoia albomaculata, sp.n., гениталии самцов: 3 - голотип, О7, ARGENTINIEN, Prov. Mendoza, S.W. Mendoza 17 km, 20 Nov 1998, Leg. A. Ugarte P., (Genitalprдparat Heterocera № 28.460) (MWM); 4 - паратип, О’, Rio Negro, Choele Choel, 17 Feb 1953, P. Köhler Leg., (Prep.Gen. MLP N³) (фронтальная и латеральная проекции) (MLP).

(Fig. 2): Neuquén: Laguna Blanca, 11 Ene 1970, Schajovskoi Leg., (MACN); $10^{7}$ Dic 1965, Köhler Leg., (FML); $4 \sigma^{7} \sigma^{7}$ Bajada Marucho, 10 Ene 1970, Schajovskoi Leg., (MACN); $10^{7}$ Lago Epulaufquen, 05 Dic 1955, Leg. Fleiss, (MLP); $10^{7}$ Isla Victoria, Feb 1955, (MLP); $10^{7}$ Villa La Angostura, 03 Ene 2006, Coll. O. Di Iorio, (IMZA); $10^{7}$ Rio Negro: Choele Choel, 17 Ene 1953, P Köhler Leg., (IMZA); $20^{7} 0^{7} 17$ Feb 1953, Col. P. Köhler, ("sp nov") "Prep.Gen. MLP N ${ }^{\circ}$, F.C.Penco" (MLP) (Fig. 4); idem, $10^{\prime}$

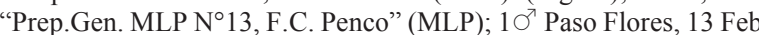
1956, "Schajovsjoy"[sic] Leg., (IMZA); $10^{7}$ Depto. Gral. Roca, Villa Regina, 08 Mar 2017, “1668”, Col. Federico D'Hervé, (MPCN); $10^{7}$ Bahía Creek, 10 Feb 2011, F.D'Hervé, (MPCN); $20^{7} \sigma^{7}$ San Juan: Pie de Palo, Quebrada Lima (1600 m) Ene 1959, A.Vetrano Leg., Coll. Orfila, (MACN); $10^{7}$ Buenos Aires: Tornquist, $22 \mathrm{Feb}$ 1993, J.R[umi] Leg., (MWM).

DESCRIPTION. Length of fore wing $16-18 \mathrm{~mm}$. Wingspan 35-38 mm. Male (Fig. 1) Thorax covered with intercalate dark and pale brown hairs. Sides of Prothorax dark brown. Two thin dark bands symmetrically fall down to both sides of Mesonotum, terminal portion of scutellum II with black hairs forming a thin transverse band, covered by the long hairs of thorax. Basis of hind wings covered with long creamy-coloured hairs. The same tone at sides of abdomen not reach the third segment, rest of abdomen dark brown. Antenna bipectinate, dark brown, basis of antenna creamy white, head with long hairs. Palpus at same tone than head. Compound eyes darker. Fore wing ground color brown, with a dense reticulation brown chocolate all around. A variable number of brands at coast, of different width, also very variable, generally the four bands near to apex thicker. Postdiscal band from the apex to the dorsal angle, thin on the coast, thicker in the intermediate space between M3 and $\mathrm{Cu} 1 \mathrm{a}$, and not reaching $\mathrm{Cu} 1 \mathrm{~b}$. In Culb it remains only as a thin line until dorsum.

In the thickest part, between the intermediate spaces M3 and $\mathrm{Cu} \mathrm{a}$, and $\mathrm{Cu} \mathrm{a}$ and $\mathrm{Cu} \mathrm{lb}$ born two bands that connect it with the margin in the middle of both spaces. The lines widen towards the margin resulting in triangular shape brown coloured. This connection between the main band and the mar- gin occurs in all the intermediate spaces from M3 to R5, but the fine lines divides at the margin and ends as two lines in "v" shape, coincident with that design, a short band creamy over the cilias, which intercalate in the dark band of margin. Postbasal curved thick brown-chocolate band, which ends at

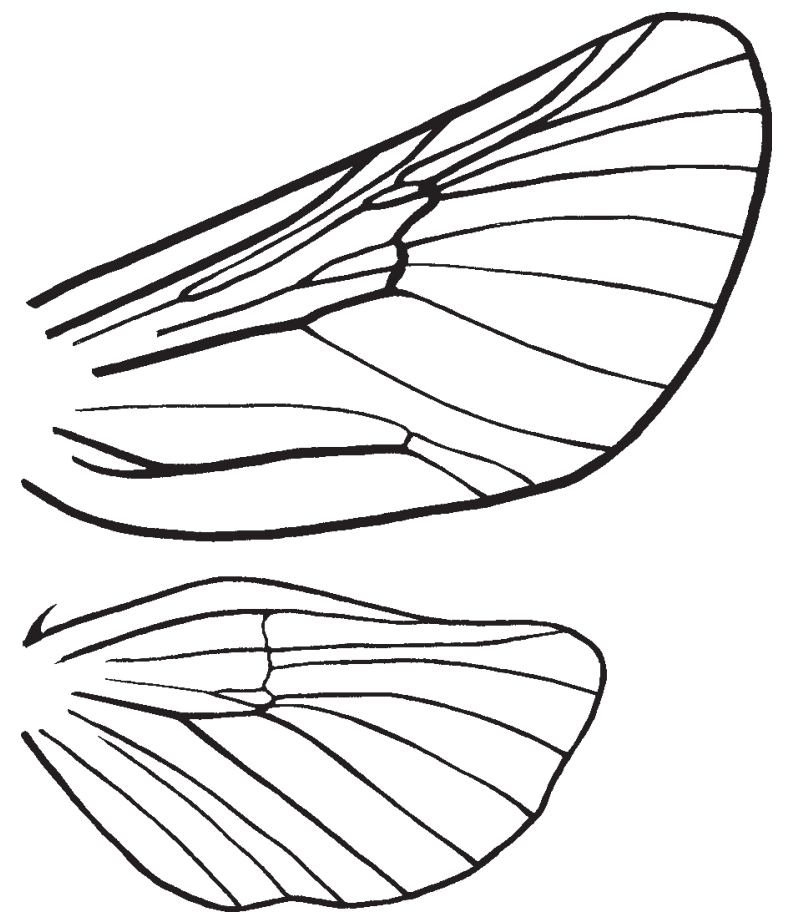

Fig. 5. Wings venation of Schajovskoia albomaculata, sp.n. Рис. 5. Жилкование крыльев Schajovskoia albomaculata, sp.n. 
1A together with a white spot semicircular, in ocations divided in two by the brown design. Below $1 \mathrm{~A}$ a variable quantity of thin lines (between 8 to 12) which reach dorsum. Margin with two thin brown lines aparted by two bands lightly thicker of creamy colored. The outer creamy band is conformed by long cilias, and are dark at tip. Hind wing rounded, creamy and with heavy brown-coloured reticulation. The lower side repeats the design of the upper side but blurred. Only highlights the design of the bands at the costa. Legs as same colour than the body. Tibia and femur covered with long hairs.

Male genitalia (Figs 3-4). See description of the Genus.

Female (Fig. 2). Shares same wing pattern than male, only distinguished by his bigger size, thicker abdomen and the margin of fore wings somewhat more rounded.

ETYMOLOGY. The name is the conjunction of the two Latin words "albo" (white) y "macula" (spot) in reference to the white spots on the medial area below the cell, which is the clearest distinguishable character in a species which has a high grade of variability in the designs on the wing pattern.

DISTRIBUTION. Known only from Argentinian provinces of Mendoza, San Juan, Neuquén, Rio Negro and southern Buenos Aires (Fig. 6).

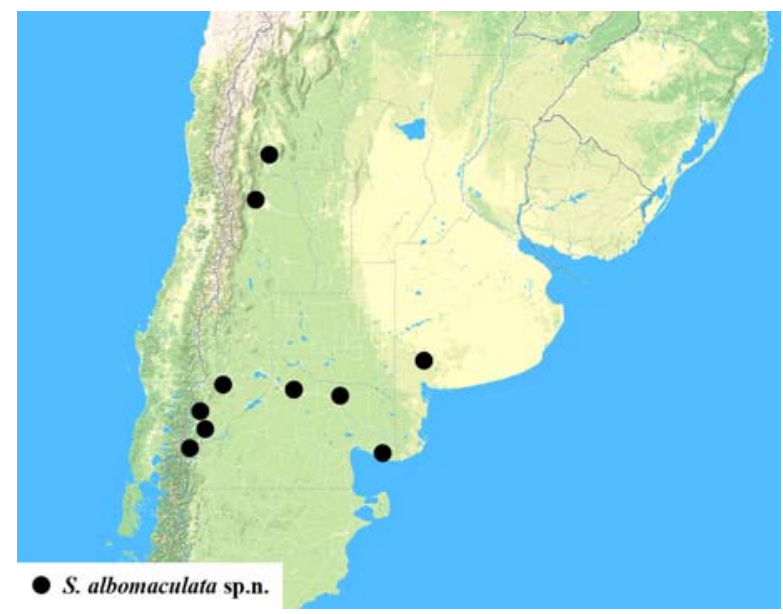

Fig. 6. Map of geographical distribution of Schajovskoia albomaculata, sp.n.

Рис. 6. Карта распространения Schajovskoia albomaculata, sp.n.

Acknowledgments. The authors are grateful to Anna Ustjuzhanina (Tomsk, Russia) and Prof. Boris Kondratieff (Fort Collins, USA) for language improvements. Dr. Arturo Roig Alsina, Ezequiel Nuñez Bustos y Joanna Rodríguez del Museo Bernardino Rivadavia, Adriana Marvaldi y Jorge Salas del Museo de La Plata, Esteban Daniel Saini y Albano Giudici del IMyZA-INTA (Hurlingham), Federico D‘Hervé y Pablo Chafrat del Museo Patagónico de Ciencias Naturales "Juan Carlos Salgado" (Rio Negro).

\section{References}

Davis S.R., Gentili-Poole P., Mitter, C.H. 2008. A revision of the Cossulinae of Costa Rica and cladistic analysis of the world species (Lepidoptera: Cossidae) // Zoological Journal of the Linnean Society. Vol.154. P.222-277.

De Mena A.M. 2014. El príncipe ruso que vivió en la Patagonia. RN 27 Jul 2014. Revista Digital. Available in: https:// www.rionegro.com.ar/el-principe-ruso-que-vivio-en-la-patagonia-YSRN_3406610/[online] last consult: 25/05/19.

Donahue J.P. 1980. Resurrection of the genus Morpheis (Cossidae), with description of a new species in the cognatus group from southern Arizona // Journal of the Lepidopterists Society. Vol.34. No.2. P. $173-181$.

Donahue J.P. 1995. Cossidae // J.B. Heppner (Ed.). Atlas of Neotropical Lepidoptera. Checklist: Part 2. Hyblaeoidea, Pyraloidea, Tortricoidea. Association for Tropical Lepidoptera. Gainesville. Fl. USA. P.122-126.

Dyar H.G., Schaus W. 1937. Familie: Cossidae // Die Gross-Schmetterlinge der Erde. Bd.6. American Fauna, Stuttgart. S.12641287.

Gentili P. 1989. Revisión sistemática de los Cossidae (Lep.) de la patagonia andina // Revista de la Sociedad Entomologica Argentina. Vol.45. Nos 1-4. P.3-75.

Gentili P. 1995. Revisión Sistemática del género Acousmaticus Butler, 1882 (Lepidoptera: Cossidae) // Acta Entomológica Chilena. Vol.19. P.21-29

Gentili P. 2008. Leg. M.O.Gentili. 27.IV.1926-10.V.2008. Obituario // Revista de la Sociedad Entomologia Argentina. Vol.67. Nos 3-4. P.165-167.

Gentili M., Gentili P. 1988. Lista comentada de los insectos asociados a las especies sudamericanas del género Nothofagus // Monografías de la Academia Nacional de Ciencias Exactas y Naturales Bs. As. Vol.4. P.85-106.

Naydenov A.E., Yakovlev, R.V., Penco, F.C, Witt, T.J. 2019. A new genus and species of the subfamily Zeuzerinae Boisduval, [1828] (Lepidoptera: Cossidae) from Brazil // Russian Entomological Journal. Vol.28. No.1. P.82-83.

Penco F.P., Yakovlev R.V., Witt T.J. 2016. Taxonomic notes on the genera Brypoctia Schoorl, 1990 and Schreiteriana Fletcher \& Nye, 1982 (Lepidoptera, Cossidae) // Zootaxa. Vol.4205. No.3. P.297-300. DOI: 10.11646/zootaxa.4205.3.10

Penco F.C., Yakovlev R. 2015. Lista comentada de los Cossidae (Lepidoptera) de Argentina // Historia Natural, Tercera Serie. Vol.5. No.2. P.79-94.

Penco F.C., Yakovlev R.V. 2017. Descripción de una nueva especie de Cossidae de Argentina (Lepidoptera: Cossoidea: Cossidae: Hypoptinae) // Historia Natural, Tercera Serie. Vol.7. No.2. P.67-76.

Penco F.C., Yakovlev R.V., Naydenov A.E. 2019a. New species of genus Breyeriana Orfila, 1957 (Lepidoptera: Cossidae: Hypoptinae) from Argentina // Ecologica Montenegrina. Vol.20. P.114-118.

Penco F.C., Yakovlev R.V., Naydenov A.E., Witt T.J. 2019b. Two new species of the genus Givarbela Clench, 1957 (Lepidoptera: Cossidae: Hypoptinae) from South Neotropics // Zootaxa. Vol.4577. No.3. P.596-600.

Schoorl J. W. 1990. A phylogenetic study on Cossidae (Lepidoptera: Ditrysia) based on external adult morphology // Zoologische Verhandelingen. Vol.263. P.4-295.

Yakovlev R.V. 2014. Redescription of the genus Miacora Dyar, 1905 from South America (Lepidoptera, Cossidae) // SHILAP Revista de lepidopterologia. Vol.42. No.165. P.57-60.

Yakovlev R.V., Penco F.C., Witt T.J. 2016. Redescription of genus Psychonoctua Grote, 1865 (Insecta: Lepidoptera, Cossidae, Zeuzerinae) // Biological Bulletin of Bogdan Chmelnitskiy Melitopol State Pedagogical University. Vol.6. No.3. P.46-50.

Yakovlev R.V., Penco F.C., Witt T.J. 2019. Review of the genus Brypoctia Schoorl, 1990 (Lepidoptera, Cossidae) with descriptions of five new species from Central in South America // Zoologicheskii Zhurnal. Vol.99. No.1. P.28-36. 